INTER NATIONAL MONETARY FUND

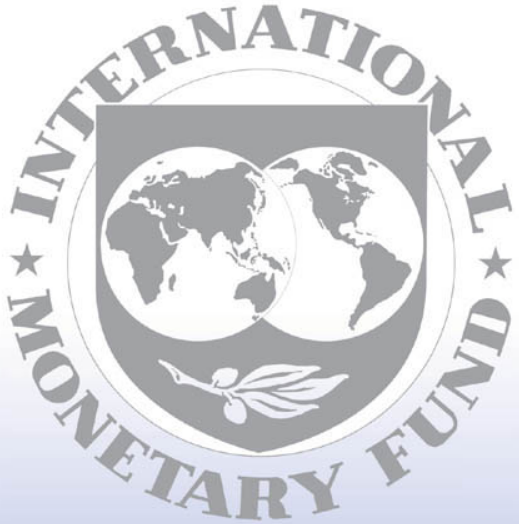

Staff

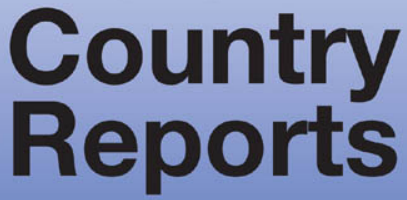




\section{Tunisia: Selected Issues}

This paper was prepared based on the information available at the time it was completed on August 12, 2009. The views expressed in this document are those of the staff team and do not necessarily reflect the views of the government of Tunisia or the Executive Board of the IMF.

The policy of publication of staff reports and other documents by the IMF allows for the deletion of market-sensitive information.

Copies of this report are available to the public from

International Monetary Fund $\bullet$ Publication Services 700 19th Street, N.W. • Washington, D.C. 20431

Telephone: (202) 623-7430 • Telefax: (202) 623-7201

E-mail: publications@imf.org •Internet: http://www.imf.org

\section{International Monetary Fund Washington, D.C.}




\section{INTERNATIONAL MONETARY FUND}

\section{TUNISIA}

\section{Selected Issues}

Prepared by Joël Toujas-Bernaté, Boileau Loko, and Dominique Simard (All MCD)

Approved by the Middle East and Central Asia Department

August 12, 2009

Contents

I. Background. .$\underline{2}$

II. Linkages with European Union Countries $\underline{4}$

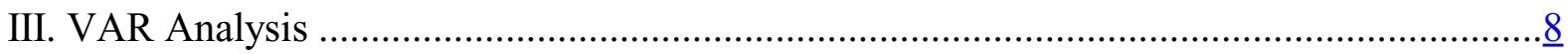

IV. Conclusion $\underline{11}$

Box

1. The Association Agreement Between Tunisia and the European Union $\underline{5}$

Figures

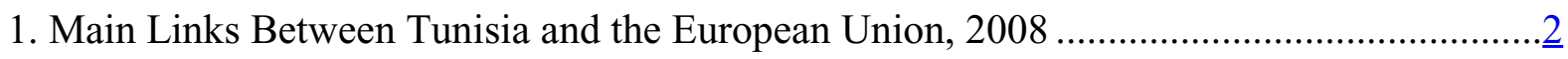

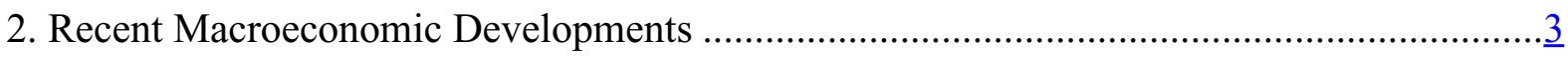

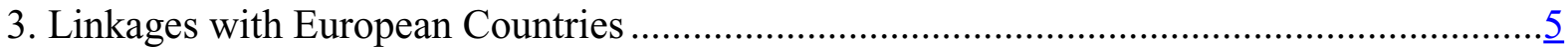

4. Output Gaps : Tunisia Versus European Trading Partners, 1987-2008 …….........................

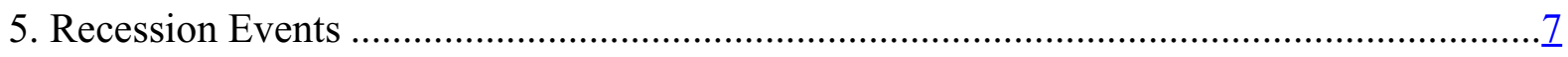

6. Evolution of Sectoral Contributions to GDP Growth ……........................................... $\underline{8}$

7. Elasticity of Tunisian GDP Growth to European Union GDP Growth ................................ $\underline{9}$

8. Forecast Error Variance Decomposition for Tunisia .................................................... 9

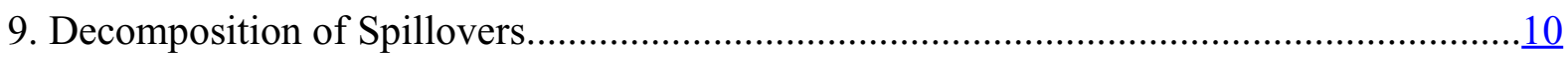

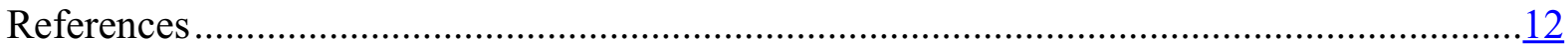

Appendices

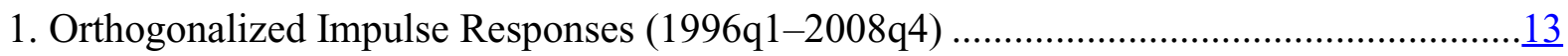

2. Orthogonalized Cumulative Impulse Reponses (1996q1-2008q4) ……............................13 


\section{INVESTIGATING GROWTH SPILLOVERS FROM EUROPE}

\section{BACKGROUND}

\section{This paper investigates how shocks to key European trading partners ${ }^{1}$ affect} economic activity in Tunisia. Tunisia's economy has been highly dependent on European Union (EU) countries for exports, tourism receipts, remittances, and FDI inflows. In 2008, between three quarters and 90 percent of these total receipts originated from the EU (Figure 1). This makes Tunisia potentially vulnerable to fluctuations in EU growth, and in particular to the current unprecedented recession experienced by EU economies.

Figure 1. Main Links Between Tunisia and the European Union, 2008

Exports of goods

(47 percent of GDP)

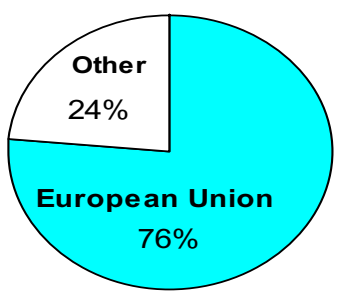

Remittances

(5 percent of GDP)

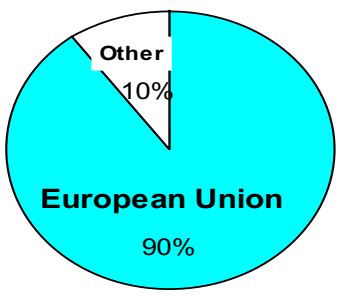

Tourism

(7 percent of GDP)

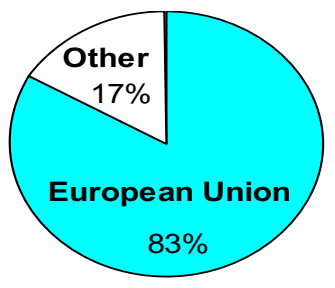

FDI inflows (6 percent of GDP)

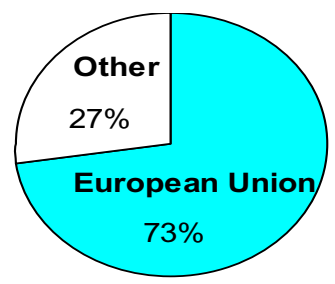

Sources: Tunisian authorities; and IMF staff estimates.

2. The first symptom of the impact of the current recession in the $E U$ on the Tunisian economy has been a sharp drop in exports of manufactured goods in end2008/early 2009. ${ }^{2}$ The industrial production has declined and overall real GDP growth slowed down from an average of 4.6 percent in 2008 to 1.3 percent (year-on-year) in the first quarter of 2009. On the other hand, tourism receipts and remittances appear to have been resilient during the first half of 2009 (Figure 2).

\footnotetext{
${ }^{1}$ In order of importance, these countries are France, Italy, Germany, Spain, the United Kingdom, the Netherlands, Belgium, Switzerland, and Austria. Real GDP of each country is weighted by its share in total Tunisian exports of goods. Exports of Tunisian goods to these countries represented 73 percent of total exports of goods in 2008 .
}

${ }^{2}$ Textile, mechanical, and electrical were the most affected sectors. 
Figure 2. Tunisia: Recent Macroeconomic Developments
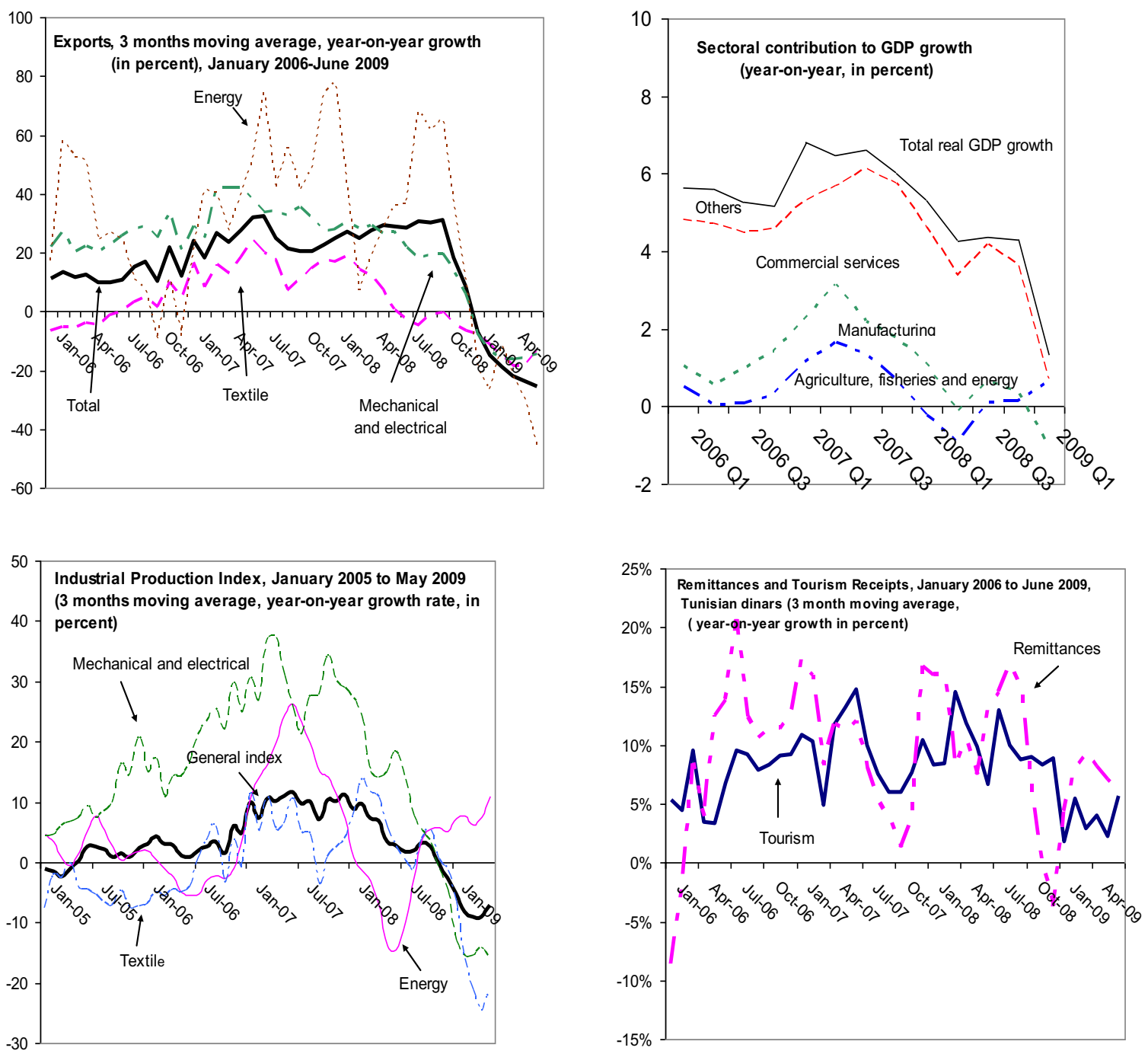

Sources: Tunisian Authorities; and IMF staff estimates.

\section{After reviewing the links between Tunisia and European trading partners, a} vector autoregression model (VAR) is estimated to assess the spillovers from Europe to Tunisia. Impulse response analysis is used to assess the size of economic linkages.

Moreover, based on methodologies used in similar studies on spillovers, the role of various potential channels of transmission is also assessed. Potential channels include financial markets, exports, tourism receipts, remittances, and FDI inflows. However, given Tunisia's 
relative insulation from international financial contagion, the analysis focused on the channels from the real sphere. ${ }^{3}$

\section{LiNKAGES WITH EUROPEAN UNION COUNTRIES}

\section{Tunisia's reliance on European countries for export earnings, tourism,} remittances, and FDI inflows has remained high over the last decades. Remittances and tourism receipts have been broadly stable in percent of GDP (Figure 3), with somewhat more fluctuations in the latter caused in part by identifiable political events which harmed tourism in the region. Export receipts in percent of GDP were also relatively stable as a share of GDP until 1998, when Tunisia intensified the opening of its bilateral trade in goods with the EU by implementing the Association Agreement (Box 1). This agreement played a significant role in opening up Tunisia's trade, as evidenced by the rising trend of its exports relative to GDP and the increase of Tunisia's trade openness (imports plus exports to GDP) from 68 percent in 1986 to almost 126 percent in 2008. It also provided Tunisia with the financial support necessary to restructure industries most affected by enhanced international competition and upgrade services - such as transports and communications - which were key to strengthening international linkages. FDI inflows from the EU have hovered between 1 and 4 percent of GDP between 1986 and 2005, but since then have followed a sharp rising trend after the European Neighborhood Policy was implemented, which aims inter alia to improve the investment climate. ${ }^{4}$

\section{Reflecting these linkages, Tunisia's annual growth rate appears to have become} increasingly synchronized over time with the annual growth rate of its main European trading partners (Figure 4). The correlation between output gaps ${ }^{5}$ in Tunisia and output gaps in its European trading partners increased from 0.33 in 1985-92 to 0.67 in 1993-2008.

\footnotetext{
${ }^{3}$ Tunisia's capital account is only partially opened, it has avoided borrowing from international capital markets since August 2007, and foreign participation in the Tunis stock exchange is mainly strategic and stable (see Text Box 1 of the staff report for the 2009 Article IV consultation).

${ }^{4}$ In particular, FDI in the energy sector increased significantly.

${ }^{5}$ Potential output is estimated using the Hodrick-Prescott (HP) filter.
} 
Figure 3. Tunisia: Linkages with European Countries
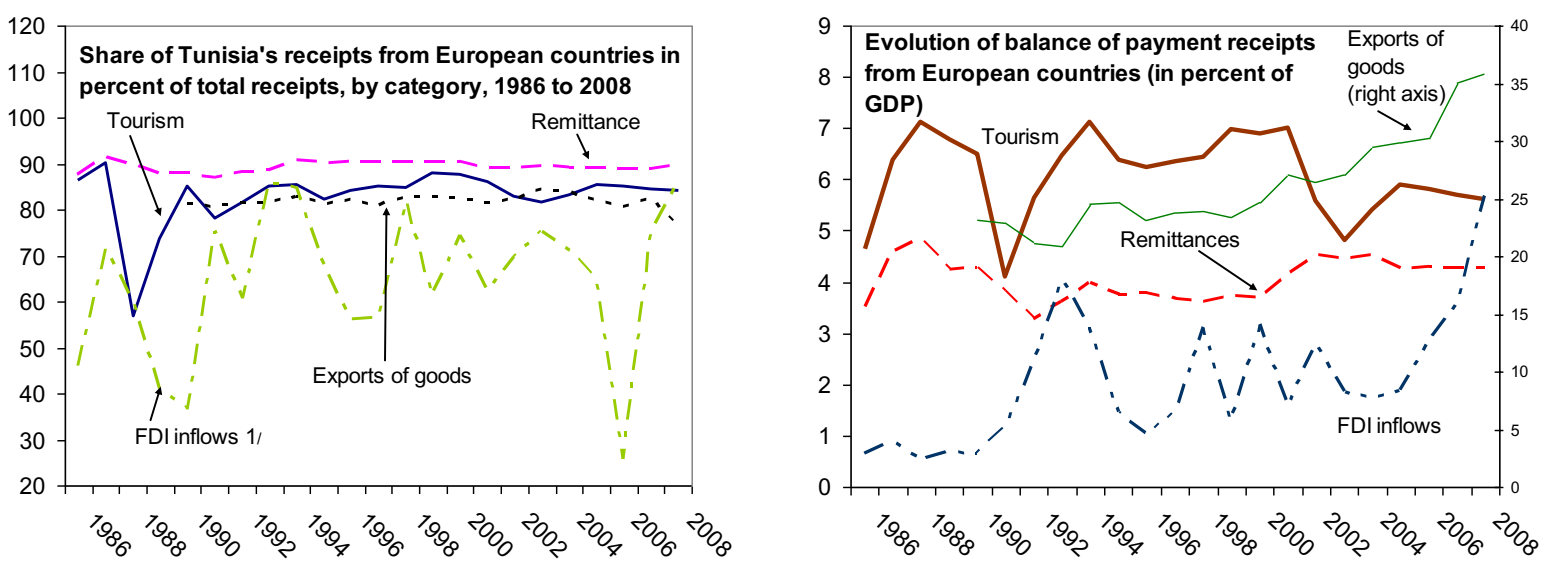

1/ Includes the privatization of Tunisie Telecom to Dubai Tecom, from the United Arab Emirates for about \$US 2.3 billions in 2006.

Sources: Tunisian authorities; and IMF staff estimates.

\section{Box 1. The Association Agreement Between Tunisia and the European Union (EU)}

To deepen its global integration and better anchor its reform strategy, Tunisia signed a bilateral Association Agreement with the EU (AAEU) on July 17, 1995 and implemented it on March 1, 1998. This agreement has been concluded in the context of a broader approach of the European Union towards widening its relations with neighboring countries from the south of the Mediterranean and aiming at the EU's long-term objective of building a Euro-Mediterranean economic area. An amendment to the AAEU covering agricultural products was implemented on January 1, 2001.

The main features of the AAEU are threefold. First, it liberalized trade relations through an immediate abolishing of quantitative restrictions and a gradual reduction of trade barriers, which culminated in free trade for industrial goods in 2008. Trade liberalization pertaining to agriculture products and negotiations to liberalize the trade of services are still ongoing. Second, it contributed to harmonizing Tunisia's regulatory framework with the one in place in the EU, particularly for trade-related policies, norms and standards including in transport and telecommunications, accounting and financial services, and statistics. Third, it provided support for sectors facing more difficulties to adjust to the trade liberalization (the "mise à niveau" program), and it enhanced cooperation, notably in the development of infrastructure.

The European Neighborhood Policy (ENP) builds on the AAEU by focusing the bilateral cooperation between Tunisia and the EU on more targeted programs. It was developed in 2004 and concluded with Tunisia in 2005. It provides increased financial support and encourages (i) enhanced regional cooperation for trade integration and development of infrastructure (particularly for energy, transport, and information technology); (ii) improvements in the business climate (particularly through streamlined taxation and customs procedures, and strengthened intellectual and property rights); and (iii) a consolidated macroeconomic framework. 
Figure 4. Output Gaps: Tunisia versus European Trading Partners, 1987-2008

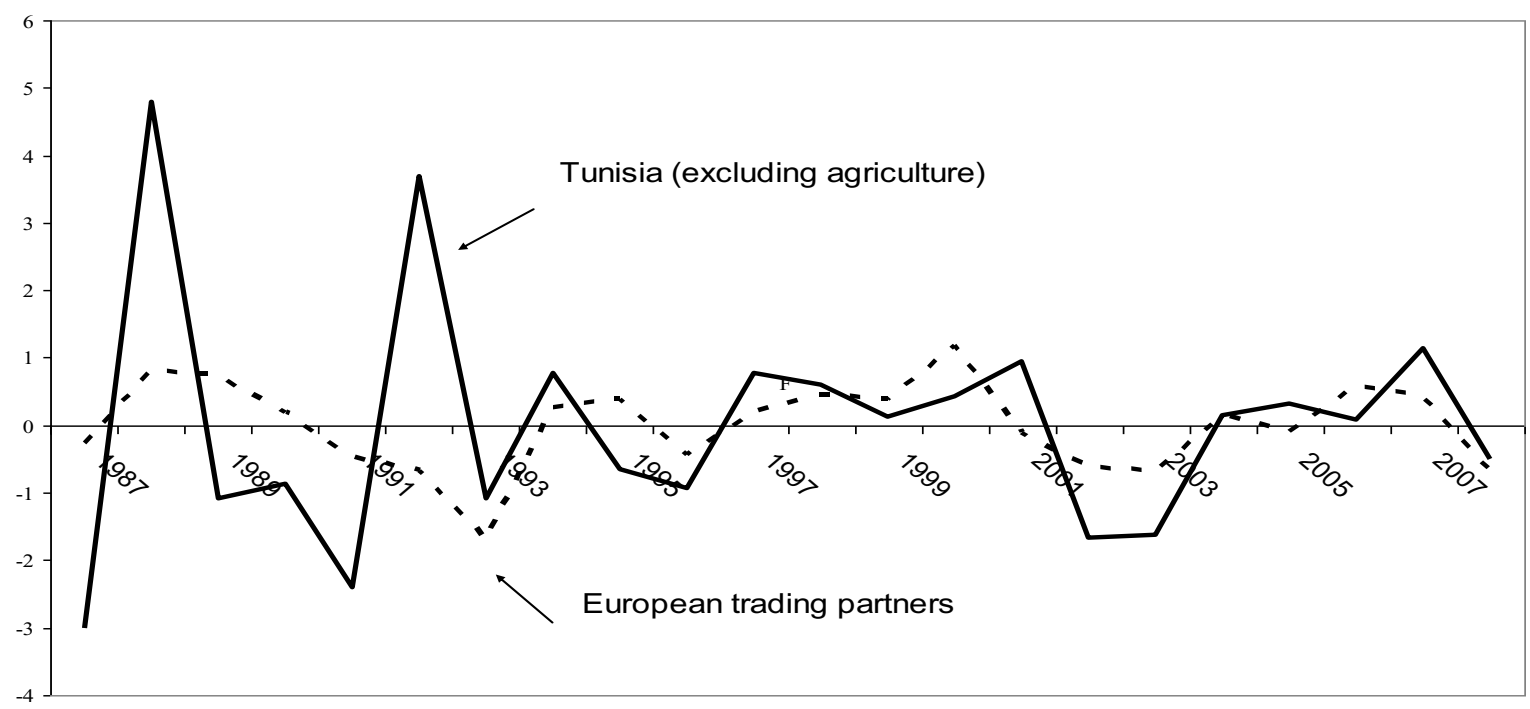

Source: Staff computations.

6. As Tunisia increased its trade openness, it experienced less variable and higher average growth rates. From 1986 to 1992, a period which includes a program with the $\mathrm{IMF}^{6}{ }^{6}$ the average growth rate of real GDP excluding agriculture was 4.2 percent and its standard deviation was 3.4 percent. From 1993 to 2008, the average growth rate of real GDP excluding agriculture and hydrocarbons was 5.1 percent and its standard deviation dropped to 1 percent.

\section{Tunisia's heightened degree of trade openness has also made it more vulnerable} to European spillovers. Indeed, the more recent episode of European recession in 2001 has impacted Tunisia's growth rate to a larger extent than the 1993 one. In 1991, there was a rapid decline in real GDP growth in Europe, which became negative in 1993. The peaks and troughs in Tunisian growth in nonagricultural GDP seem to occur in the vicinity of similar turning points in its trading partners (Figure 5). However, the correlation between output gaps with Europe appears relatively weak at 0.05 . In contrast, the 2001 recession in Europe has had a significantly larger impact on Tunisian growth than the 1993 recession, with a correlation between the output gap in Tunisia and the output gap in European partner countries increasing to about $0.7^{7}$

\footnotetext{
${ }^{6}$ Extended Fund Facility (EFF) from 1988 to 1992.

${ }^{7}$ The April 2002 terrorist attack in Djerba also hit the economy with tourists arrivals and tourism nights dropping by 6 percent and 22 percent respectively in 2002. Tourism receipts fell by 13.5 percent.
} 
Figure 5. Tunisia: Recession Events
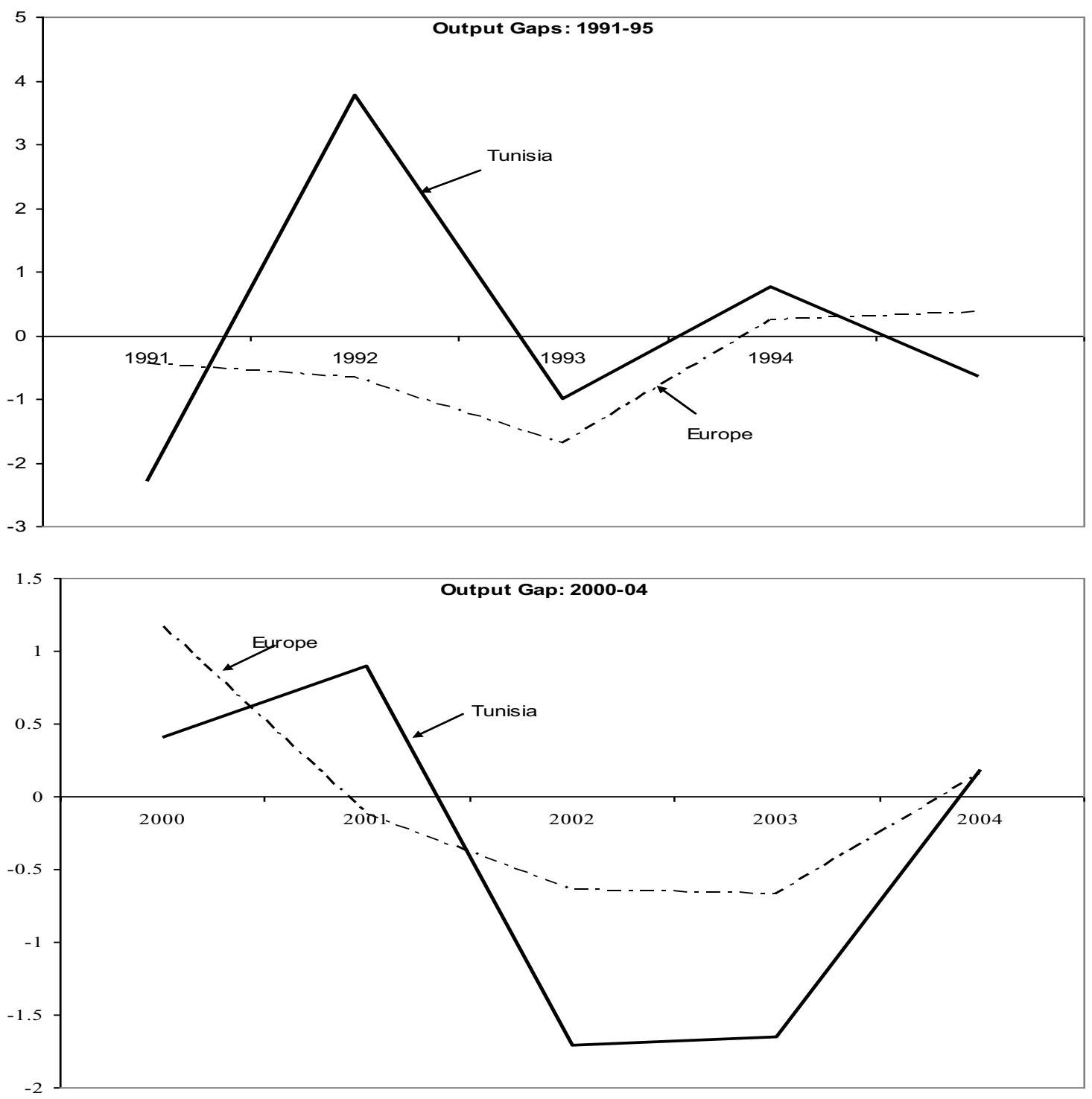

Source: Staff computations.

8. The structure of the Tunisian economy has evolved in the last twenty years, with an increased reliance on services and, to a lesser extent, on mechanical and electrical industries as factors for real GDP growth. Services now represent about 50 percent of GDP (in real terms), of which less than 5 percent is tourism. These sectors contributed twothirds of real GDP growth in the last few years, with the bulk coming from transport and telecommunication (Figure 6). In contrast, the contribution of the agriculture, fishing, and textile sectors has faded over time. While activity in many of the services sectors (excluding tourism) is not directly linked to EU countries, it is likely to rely on and be affected by activity in sectors directly exposed to the EU, such as tourism or goods exporting sectors. 
Figure 6. Tunisia: Evolution of Sectoral Contributions to GDP Growth (In percentage points, period average)

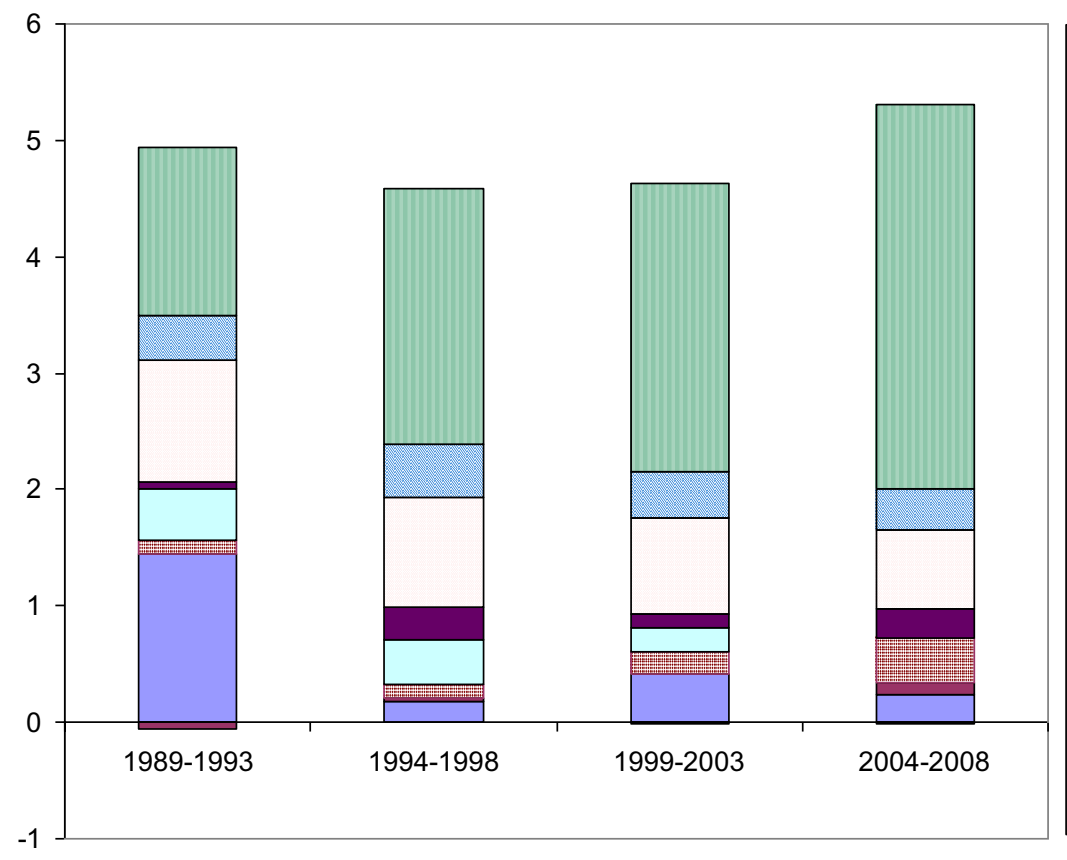

$\square$ Other services

$\square$ Other manufactures

$\square$ Other

Tourism

$\square$ Textiles, clothing, and leather

国 Mechanical and Electrical Industries

Hydrocarbons

Agriculture and Fishing

Sources: Tunisian authorities; and IMF staff estimates.

\section{VAR ANALYSIS}

\section{The dynamic responses of growth in Tunisia to Europe shocks are analyzed} using a vector autoregression (VAR). The VAR is estimated using quarterly data over 1996-2008, the period covering the AAEU, including the year following its announcement. The VAR includes real GDP growth in Tunisia and in Europe (the causal ordering is growth in European partners and growth in Tunisia). ${ }^{8}$

\section{The results show sizeable and significant growth spillovers from Europe to}

Tunisia. The impulse response functions (IRFs) suggest that a shock to key partners' economies affects real GDP growth rate in Tunisia within a year (see Appendix). A shock to growth in Europe has a relatively strong contemporaneous impact equivalent to 22 percent of the initial shock, and reaches a peak after three quarters. The impact persists for seven to eight quarters before fully dissipating. Overall, the apparent elasticity of Tunisia growth in

\footnotetext{
${ }^{8}$ We consider year-on-year growth in real GDP excluding agriculture, which also removes seasonal effects. Both Akaike and Schwarz criteria suggest that two lags are sufficient to capture the dynamics of the variables.
} 
real GDP (excluding agriculture) to growth in EU partners is about $0.9^{9}$ over an 8-quarter horizon (Figure 7). These results remain robust to an augmented VAR that includes the potential impact of common shocks such as fluctuations in oil prices. ${ }^{10}$

Figure 7. Tunisia: Elasticity of Tunisian GDP Growth to EU GDP Growth

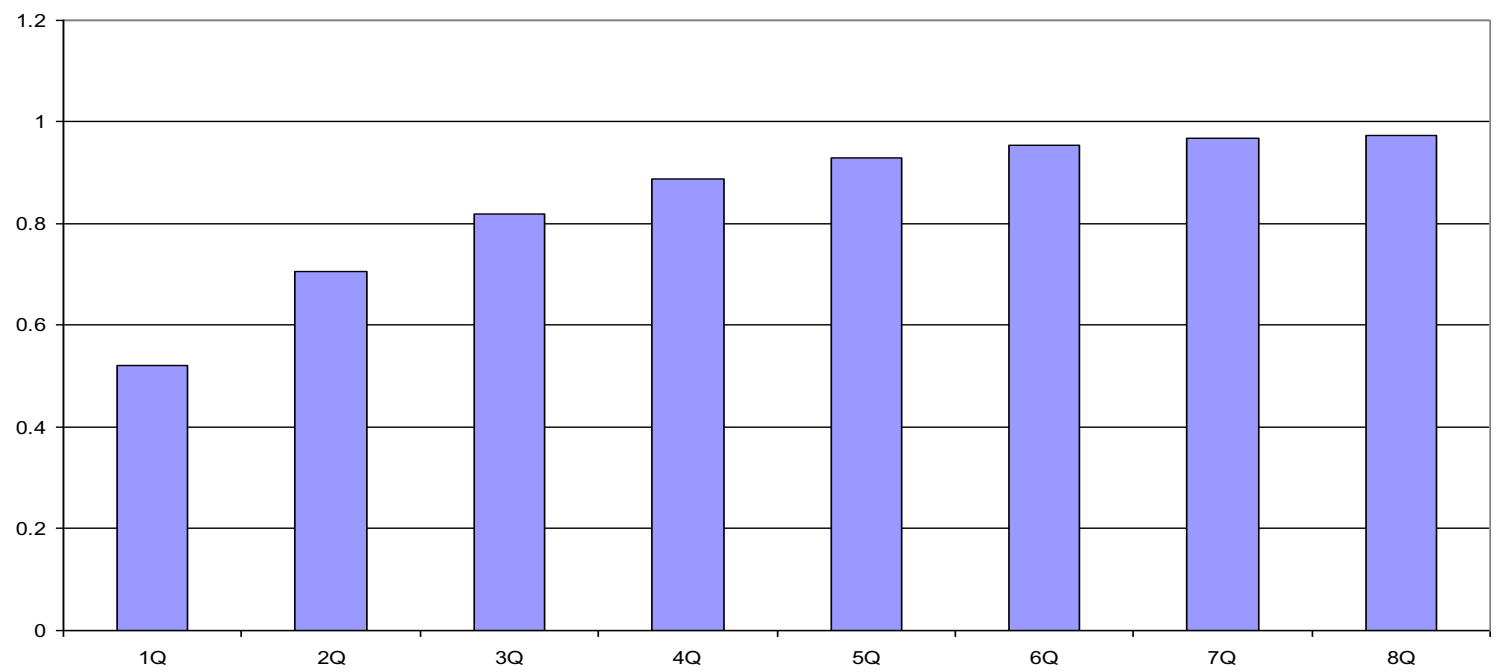

Source: Staff calculations.

\section{The analysis of the forecast}

error variance decomposition also suggests that shocks in Europe play a non-negligible role in fluctuations of Tunisia growth. The forecast error variance decomposition is computed at over an 8-quarter horizon. As shown in Figure 8, the share of the forecast error variance of growth in Tunisia that can be explained by shocks to European GDP growth increases from 6 percent after

Figure 8. Tunisia: Forecast Error Variance Decomposition for Tunisia Growth

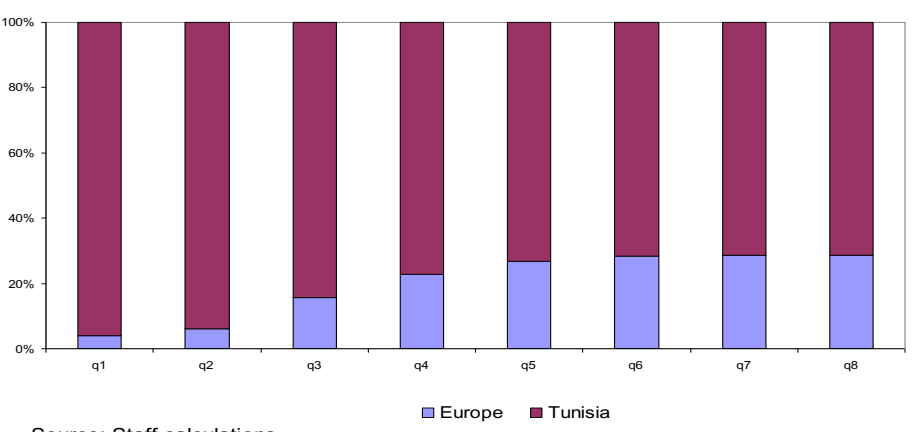

2 quarters to almost 30 percent after 8 quarters.

\footnotetext{
${ }^{9}$ The elasticity remains unchanged at 0.9 across samples (1998q1-2008q4, 2001q1-2008q4) after the AAEU. However, when using a larger sample covering also the period before the AAEU (1993q1-2008q4), the elasticity falls to about 0.7 percent.

${ }^{10}$ The VAR was augmented with the relative price of oil deflated by the US CPI. Results are available upon request.
} 


\section{We attempt to identify the major channels through which shocks to Europe GDP} are transmitted to Tunisia, using the approach introduced by Bayoumi and Swiston (2008). The methodology consists of augmenting the baseline VAR by adding each of the potential transmission channels as exogenous variable. ${ }^{11}$ The difference between the response from the augmented VAR and the response from the baseline VAR represents the individual channel's contribution. The potential channels explored are trade, tourism, remittances, and FDI inflows.

\section{The results indicate that both trade and tourism are important transmission} channels of spillovers from Europe to Tunisia. The trade channel is captured by growth in exports of goods (in volume) ${ }^{12}$ while growth in the number of tourist entries is used for tourism. The two channels contribute equally to the transmission of shocks from Europe to Tunisia with increasing cumulative effects. Together, they account for more than half of cumulative spillovers after five quarters (Figure 9). Remittances contribute to the contemporaneous transmission of shocks, but its effect dissipates after two quarters. ${ }^{13}$ FDI did not appear to transmit much of the shocks. ${ }^{14}$

Figure 9. Tunisia: Decomposition of Spillovers

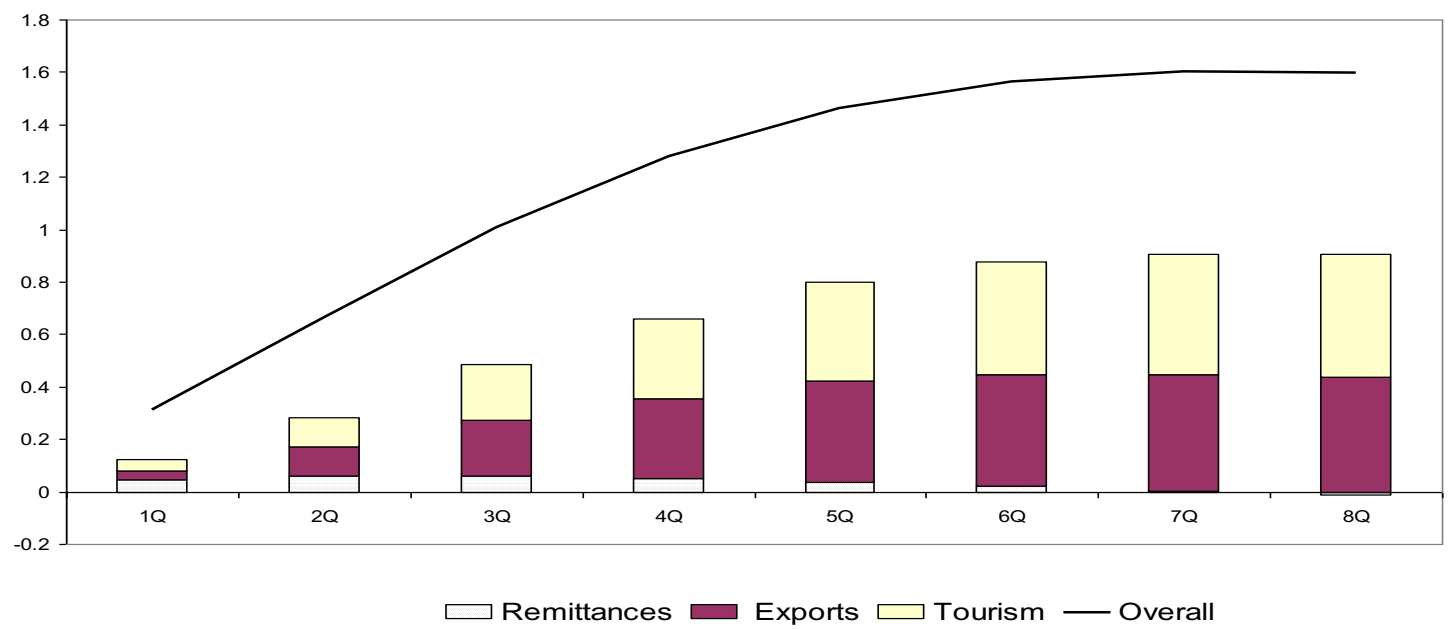

Source: Staff calculations.

\footnotetext{
${ }^{11}$ This approach is based on the assumption that the transmission channels introduced in the augmented VAR are mainly a function of foreign factors with no contemporaneous correlation with home-country factors.

${ }^{12}$ Due to data limitations, we use the volume of total exports.

${ }^{13}$ A quarterly series was constructed for observations prior to 2004. Full results are available upon request.

${ }^{14}$ This may also reflect difficulties in constructing a quarterly series for FDI, which is available only annually.
} 


\section{Conclusion}

\section{Tunisia's enhanced integration with European economies has likely increased its} receptivity to the transmission of their shocks, notably through exports and tourism. A VAR analysis indicates that growth shocks in the main EU partners of Tunisia have relatively large spillover effects on Tunisia growth. These shocks appear to be transmitted mainly through the export and tourism channels. While these sectors have limited direct contributions to Tunisia GDP, they likely affect and drive important service sectors which have greatly contributed to Tunisia's growth performance in recent years.

\section{The results imply that the current recession in the EU presents significant} downside risks for Tunisia, which may further materialize in the next few quarters. The findings that the impact of a shock in EU growth peaks after three quarters indicate that Tunisia may yet experience the full effect on its economic activity from the European recession. Moreover, the apparent elasticity of 0.9 of Tunisia's real GDP growth (excluding agriculture) to the rate of real GDP growth in European partner countries suggests that the currently forecasted recession in Tunisia's European trading partners in 2009 will weigh on Tunisia's growth in the short term. Factors that may mitigate this outlook include the positive impact on growth of an exceptional year for agriculture and hydrocarbon activities and the early adoption of proactive policies to sustain domestic demand. Also, so far in 2009, and in contrast with past episodes of shocks, tourism receipts did not decline, which, if confirmed during the second half of the year, would lessen the overall impact on Tunisia growth. Tourism receipts have been resilient because Algerian and Libyan tourists have compensated for the drop in European tourists, suggesting that regional integration can play a key role in overcoming the global economic crisis. By strengthening regional ties, Tunisia can build more resilience to an uncertain and changing external environment. Overall, Tunisia has prospered and will continue to gain from deepening trade integration, which should also allow its economy to more fully benefit from the projected rebound in the activity of its partner countries over the medium term. 


\section{References}

Bayoumi, T. and A. Swiston, 2007, "Foreign Entanglements: Estimating the Source and Size of Spillovers Across Industrial Countries," IMF Working Paper No. 07/182 (Washington: International Monetary Fund).

No. 08/3 (Washington: International Monetary Fund).

International Monetary Fund, 2008a, "Can Asia Decouple? Investigating Spillovers from the United States to Asia," Regional Economic Outlook: Asia and Pacific, Chapter 2 (Washington: April).

International Monetary Fund, 2007, World Economic Outlook (Washington: April).

Kanda, D., 2008, "Spillovers to Ireland," IMF Working Paper No. 08/2 (Washington: International Monetary Fund). 


\section{Appendices}

Graph1a. Orthogonalized Impulse Responses (1996q1-2008q4)
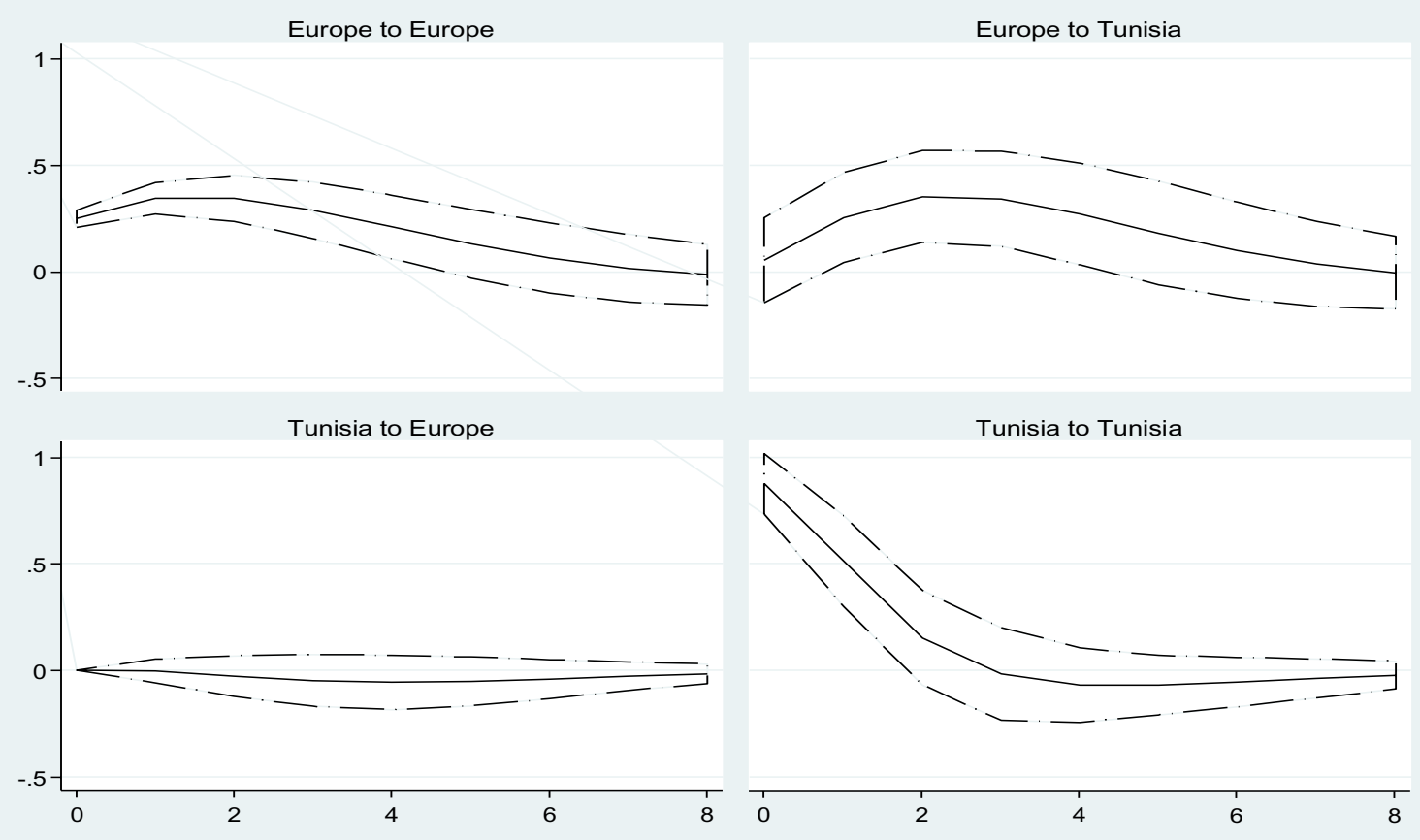

Graph1b. Orthogonalized Cumulative Impulse Responses (1996q1-2008q4)

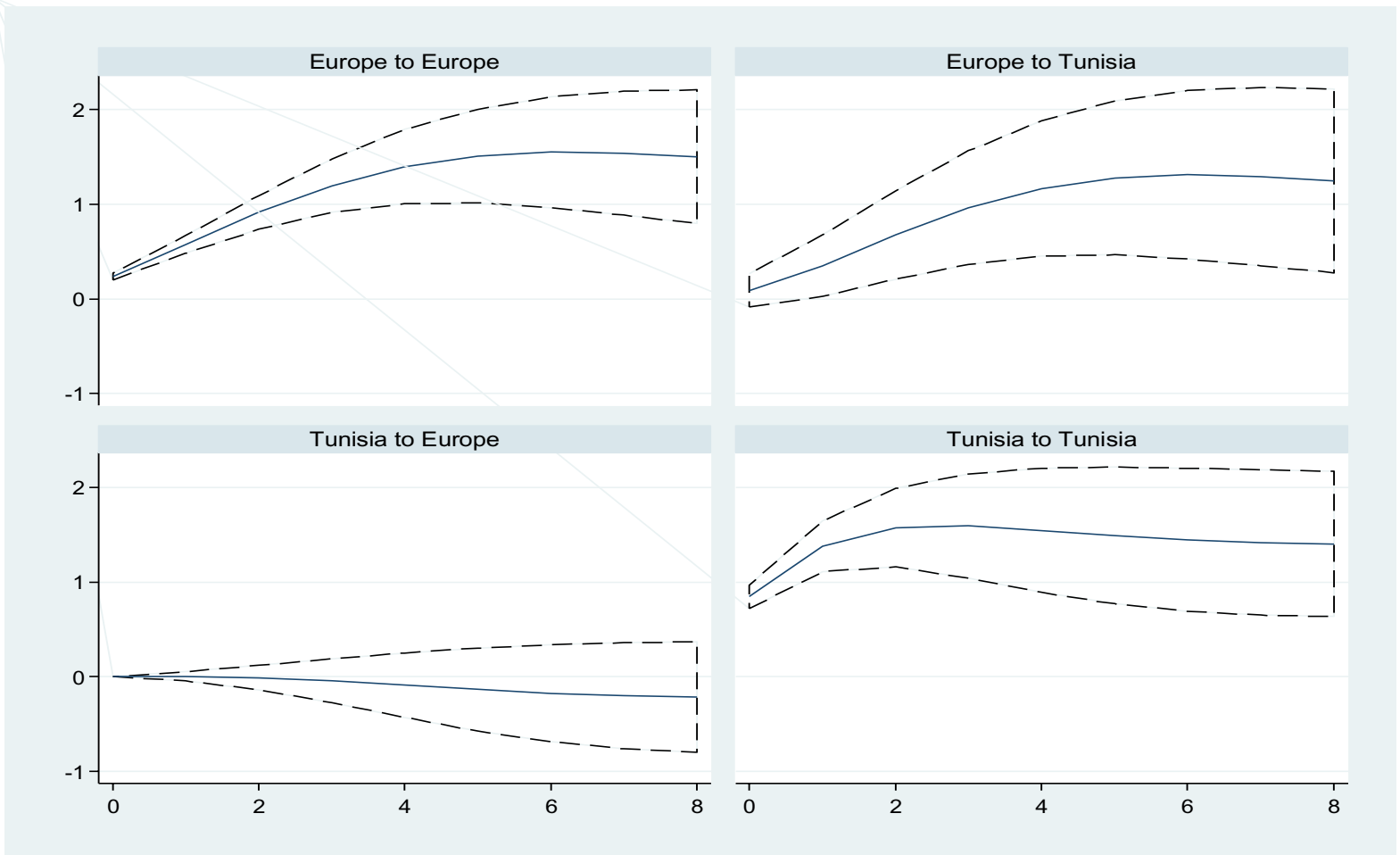

The Charts report the impulse response functions and the associated 90 percent confidence bands. 